Historic, Archive Document

Do not assume content reflects current scientific knowledge, policies, or practices. 



\section{The Mount Desert Nurseries}

\section{Bar Harbor, . . Maine}

$$
\text { ॠ } 1920 \text { ॠ }
$$

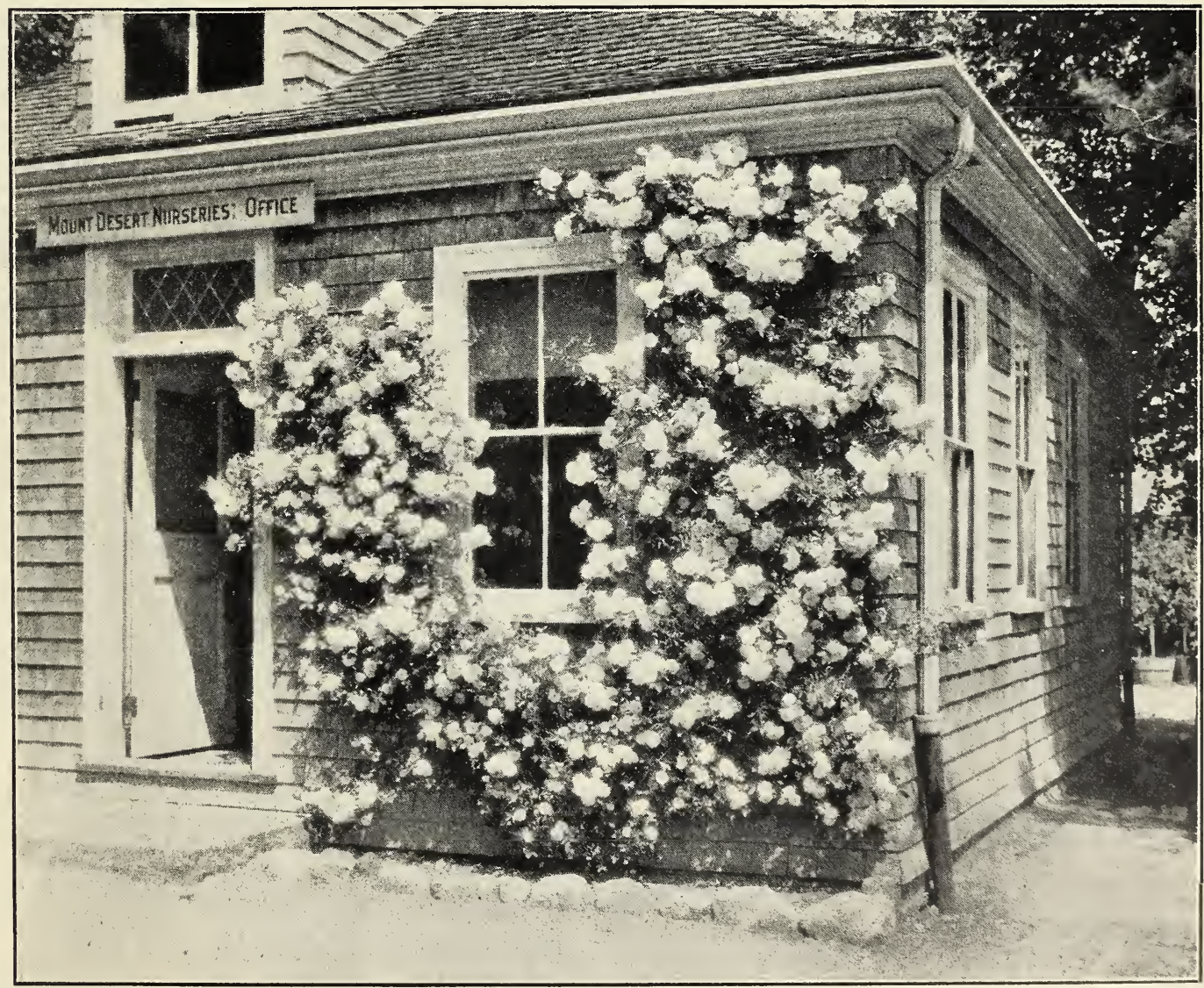

Roses, Bedding Plants, Vegetable Seeds, Etc. 


\section{ROSES}

We recommend the following to those who wish a limited number of varieties, and who desire to produce extra choice flowers throughout the summer and fall months. All have been tested and proved to be the best obtainable for our climate.

\section{Hybrid Teas}

Caroline Testout. Satin rose with brighter center. Large, full flower, and a very free bloomer.

CHRISSIE MacKELLER. Coppery yellow, overlaid with golden-rose; very free blooming.

ETOILE DE FRANCE. Velvety crimson; large and full. A strong grower and a superb rose in every way.

FRAU KARL DRUSCHKI. Pure white. Very large buds, opening to large, full flowers. Finest white rose in cultivation.

GEORGE ARENDS. (Pink Frau Karl Druschki). A beautiful variety of recent introduction, producing immense flowers of a delicate rose color. Deliciously scented.

KAISERIN AUGUSTA VICTORIA. Pearly white, tinted with lemon in the center. Beautifully formed flowers on long stems.

KILLARNEY. A sparkling, brilliant pink. Flowers are large, and buds long and pointed. A strong and vigorous plant.

MISS KATE MOULTON. Very beautiful shell pink.

PRICE:-Any of the above, $\$ .90$ each; $\$ 7.50$ per 10.

\section{Hybrid Perpetuals}

BARONESS ROTHSCHILD. Pale satiny-rose; very large flower.

HUGH DICKSON. Brilliant crimson, shaded scarlet; Finest of all crimson varieties.

MRS. JOHN LAING. Soft pink; very large, and of fine form.

PAUL NEYRON. Deep rose. Immense flowers; strong and hardy.

ULRICH BRUNNER. Cherry red; of immense size, and most effective. A superb rose of vigorous growth which should be in every garden.

PRICE:-Any of the above, $\$ .90$ each; $\$ 7.50$ per 10.

\section{Hardy Climbing and Trailing Varieties}

AMERICAN PILLAR. A single flowering variety of a lovely shade of pink, with a clear white eye.

DOROTHY PERKINS. Soft shell pink, flowering freely in large clusters.

WHITE DOROTHY PERKINS. A white form of the above. Probably the best white climber there is.

HIAWATHA. A single flowering rose; deep carmine with a clear white eye.

LADY GAY. One of the best of the climbing roses, bearing large clusters of soft pink double flowers.

LA FIAMMA. Large clusters of flame-colored flowers, borne on long stems. Single. 
LUCILLE. Double blooms of a delicate flesh-pink tinged with rosy-salmon, produced in large clusters.

TAUSENDSCHON. This climbing rose stands at the head of those best adapted to our climate. Its flowers, which are of a beautiful shade of soft pink, are about two inches across, and borne in large clusters. Foliage is very glossy, and does not mildew.

TRIER. A lovely double creamy white, with yellow anthers. Bushy in habit.

PARADISE. Single. Beautiful shade of pink with white center. Very vigorous grower.

WICHURAIANA. Beautiful fragrant single pure white flowers.

NOTE-The above are two-year-old Roses, grown one year in the open ground and one year in pots. They will be sold from five and six inch pots.

Price:-Any of the above, $\$ 1.00$ each.

\section{BEDDING PLANTS}

Our Bedding Plants are started early, grown in cool houses to produce compact, stocky plants that are of the hardiest possible character. These will be ready for delivery from the last of May to the first of August:

ABUTILON SAVITZI. Variegated foliage, marked green and white. From 4 -inch pots............

ALYSSUM, Little Gem. A compact variety of Sweet Alyssum, used for edgings, etc. . . . . . . . . . . .

AGERATUM. Valuable for their long period of blooming, and for their attractive blue shades.

ANTIRRHINUM (Snapdragons) Probably the most valuable and satisfactory of plants for summer bedding, offered in all the separate colors. From flats From 3 1-2 inch pots...................

ASTERS. Grown from the choicest American seed. Offered in separate varieties and colors...........

BEGONIAS. Tuberous Rooted. To be grown at their best, these should have partial shade. Strong plants from flats. . . . . . . . . . . . . . . . . . From 4-inch post. ......................

BELLIS PERENNIS (English Daisy) In bloom for entire season........................

BACHELOR BUTTONS (Cornflowers) Offered only in the blue varieties, single and double..........

CALENDULA (Pot Marigold) Blooms all summer...

CALLIOPSIS. Showy annuals in various shades of yellow, blooming throughout the season.........

CARNATIONS. Strong plants of the most popular varieties from 4 -inch pots for summer flowering. . . .

GANNAS. We are offering exceptionally good stock from 4 -inch pots in the standard varieties. . . . . . . . . . each dozen 100

$1.80 \quad 12.00$

.80

1.50

10.00 
CELOSIA (Cockscomb) Showy and easily cultivated. Large, brilliant comb-like flower heads..........

COSMOS. Pot grown plants of the early flowering varieties

DIANTHUS HEDDEWEGII. Double flowering varieties which are almost as fine for cutting as Carnations .

GERANIUMS. These are standard varieties which have been proved to be best for Maine. All are from 4-inch pots.

A. Ricard. Large flowering scarlet variety. Semi-double.

Beaute Poitevine. Salmon pink. Conceded to be the best of its color.

La Favorite. Large flowering double white..... .

Paul Crampel. Single. A dazzling rich scarlet.

S. A. Nutt. Undoubtedly the best of the dark red Geraniums. . . . . . . . . . . . . . . . . . . . . .

Rose Scented. Old fashioned variety, with strongly scented foliage. . . . . . . . . . . .

Mme. Salleroi. Bright green leaves, edged white. Used for edging purposes . . . . . . . . . . . . .

HELIOTROPE. Very fragrant plants, ard great favorites for summer bedding. . . . . . . . . . . . .

LEMON VERBENA. Every garden should have at least a few of these plants which are grown for their fragrant foliage. . . . . . . . . . . . .

LOBELIA. Both the dwarf and trailing varieties . . . . . . MARGUERITE (Paris Daisy) Both single and semidouble white varieties. From 4 -inch pots . . . . . . .

MARIGOLDS. We offer both the African and French, tall and dwarf varieties, in their several shades of yellow and orange. .

NASTURTIUMS. Of the easiest cultivation, and provide a wealth of color and bloom throughout the summer............................

NICOTIANA. Tuberose-flowered Tobacco ...........

PANSIES. Plants in all the different shades, from the open ground, from seeds sown last August. Best varieties

PENTS'TEMONS. These are among the best of bedding plants for giving continuous blcom in the garden from the middle of July until killed by frost. Mixed

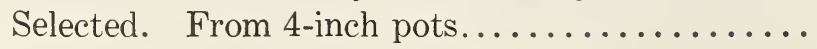


PETUNIAS. Single white and pink, and also Ruffled

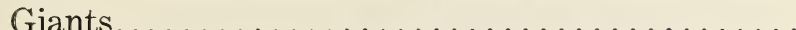

PHLOX DRUMMONDI. Easily cultivated hardy annuals. The flowers are of long duration and of the most gorgeous and varied colors . .............

SALVIA. We offer the varieties Bonfire (Scarlet Sage), Patens (Blue Sage) and Zurich (Dwarf Scarlet

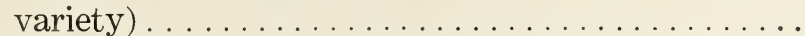

SALPIGLOSSIS. Large funnel-shaped flowers, beauti-

$\begin{array}{lll}.20 & 2.40 \quad 15.00\end{array}$
fully pencilled and veined in rich shades of yellow, crimson and purple. Fine for cutting..........

SCABIOSA. (Mourning Bride) Offered in a great variety of colors... . . . . . . . . . . . . . . . .

STOCKS. We offer plants from selected seed, and can supply them in separate colors...............

SWAINSONIA. This delightful plant bears racemes of pure white sweet pea-like flowers, and is a great favorite with all. From 4 -inch pots . . . . . . . . . .

SWEET PEAS. We offer plants of these grown in $31-2$ inch pots. The choicest orchid-flowering varieties. In estimating the number of plants needed allow for planting about one foot apart in the row . . . . . . . .

VERBENAS. Plants in separate colors, including the favorite pink variety, Miss Willmott . . . . . . . . . .

ZINNIAS. Old-fashioned garden favorites...........

\section{ANNUAL CLIMBERS}

COBEA SCANDENS. A very rapid growing climber, with attractive large purple flowers . . . . . . . . . .

GERMAN IVY. A rapid growing vine, largely used for window boxes.

VINCA. This is undoubtedly the most satisfactory of vines for the planting of window boxes, urns and vases. We offer both the green and variegated foliage varieties in strong plants from 4 -inch pots. 


\section{VEGETABLE PLANTS}

The following Vegetable Plants are grown from the best selected seed. These have all been trarsplanted into boxes, and are not to be confused with plants which are offered as seedlings.

CABBAGE. Summer . Winter.

GAULIFLOWER. Extra early Erfurt and Early Snowball

CELERY. White Plume, Golden Self Blarching, and Boston Market. . .

CUGUMBER.

LETTCGE. Black Seeded Tennisball and Trianon Cos PARSLEY

NEW ZEALAND SPINACH

TOMATOES. From flats....

From 4-irch pots

$\begin{array}{cc}\text { Dozen } & \text { Flat of } 60 \text { Plants } \\ .25 & 1.00 \\ 25 & 1.00 \\ .35 & 1.25\end{array}$

$.40 \quad 1.50$

.75

.25

.35

.35

.40

.75

NOTE:- When plants are taken in flats it will be necessary for us to charge 25 cents additional for each.

\section{GLADIOLI}

Of summer blooming bulbs for general garden planting the Gladioli are deserving of special mention. The varieties which we list below are all ones that have been tested, and are deservedly the most popular in their respective colors.

AMERICA. A beautiful soft, light pink, considered to be the finest variety introduced for bedding purposes .

Dozen 100

AUGUSTA. One of the older varieties which yet remains a general

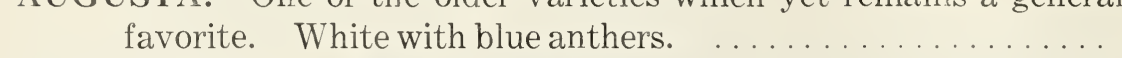

1.00

6.00

BARON HULOT. A rich violet blue.

1.00

6.00

FIRE KING. Large blooms of intense scarlet. .

1.25

8.00

HALLEY. A very large, lovely salmon pink. One of the earliest to flower.

MRS. FRANCIS KING. A striking shade of light scarlet or plum

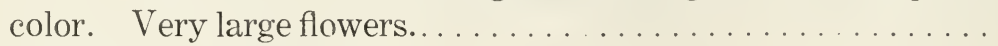

MRS. FRANK PENDLETON. A new variety. Large salmon pink, with blood red blotch at the throat. One of the finest color combinations

1.00

1.00

6.00

1.00

6.00

1.25

8.00

NIAGARA. A delicate, creamy yellow, with throat lightly penciled with rosy carmine

PANAMA. Similar to America, and has all its good qualities, but in color a rich rosy pink . . . . . . . . . . . . . . . . . .

PEACE. Immense pure white flowers, with carmine in the lower

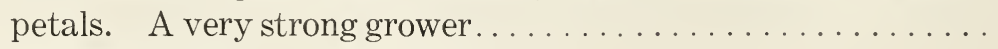

SPECIAL MIXTURE. Groff's Hybrids

$1.25 \quad 8.00$

$1.50 \quad 9.00$

$1.25 \quad 8.00$

$.50 \quad 3.50$




\section{DAHLIAS}

In Dahlias we are confining ourselves to a short list of Cactus, Peony Flowered and Decorative varieties, offering only the best under each class, and those in distinct colors.

BOQUET ROSE (Cactus) Dwarf, compact habit; lovely rose-colored blooms,

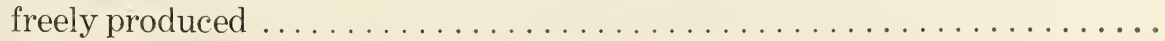

GHATENAY (Peony Flowered) A splendid flower. Carmine rose, on long, stiff stems.

each

GOUNTESS OF LONSDALE (Cactus) A pleasing shade of salmon pink and

COUNTESS OF LONSDALE (Cactus) A pleasing shade of salmon pink and
amber. Blooms freely under all conditions ....................

DELICE (Decorative) A glowing rose pink, with long, stiff stems. One of the best for cutting purposes . . . . . . . . . . . . . . . . . . . .

DREER'S WHITE (Show) A pure, glistening white, easily grown and very

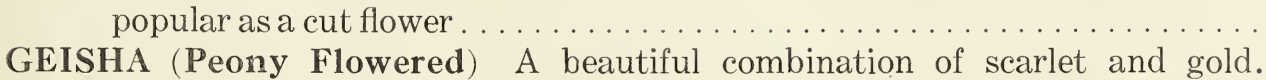
One of the most attractive . . . . . . . . . . . . . . . . . . . . .

LA FAVORITE (Cactus) Deep salmon rose, with long tubular petals . . . . . . .

LIBELLULE (Cactus) Sulphur yellow, shaded with red. Exceptionally free

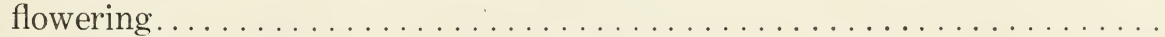

NANCY MAY (Cactus) An intense scarlet with maroon shadings. Very free

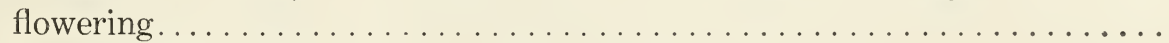

WILLIAM AGNEW (Decorative) Rich dazzling carmine red ............

NOTE:- As the season advances we will offer started bulbs of the above in 6 -inch pots at a slight advance in price. We will also be able to offer strong plants grown from cuttings in some of the above varieties.

\section{VEGETABLE SEEDS}

\section{ASPARAGUS ROOTS}

Conover's Colossal.

\section{BEANS}

Green: Bountiful. Flat Pod ................. .35

$\begin{array}{ccr}\text { Pint } & \text { Quart } & 4 \text { Quarts } \\ .35 & .60 & 2.25 \\ .35 & .60 & 2.25 \\ .35 & .60 & 2.25 \\ .35 & .60 & 2.25 \\ .35 & .60 & 2.25 \\ .35 & .60 & 2.25 \\ .35 & .60 & 2.25 \\ .35 & .60 & 2.25 \\ .35 & .60 & 2.25 \\ .45 & .70 & 2.75 \\ .35 & .60 & 2.25\end{array}$

Early Mohawk. Flat Pod ................. . 35

Early Valentine. Round Pod............... .35

Stringless Green Pod....................

Wax: Improved Golden.......................

Hodson. . . . . . . . . . . . . . . . . . . . . .

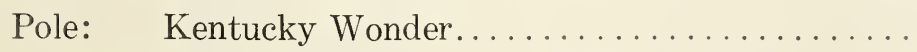

Horticultural . . . . . . . . . . . . . . . . . .

Golden Cluster.

Scarlet Runner. .

.35

60

2.25

2.25

2.25

2.25

2.25

2.25

2.25

2.25

2.25

2.75

Lima: Henderson's Bush . 


\section{BEETS}

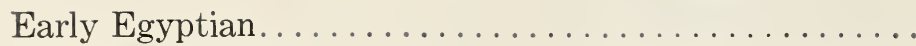

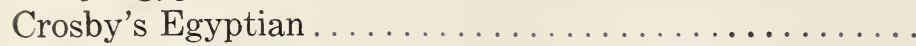

Edmund's Blood Turnip.....................

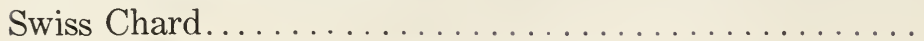

Mangel Wurzel, Mammoth Long Red.

BROCGOLI oz.

.20

.20

.20

.20

.10

.40

BRUSSELS SPROUTS

Matchless

CABBAGE

Early Jersey Wakefield

Big Winner Wakefield

Copenhagen Market. .

Danish Ball Head.

Premium Flat Dutch .

Red Dutch.

GARROTS

French Forcing

Chatenay.

Danvers Half Long.

Long Orange .

CAULIFLOWER

pkt.

Extra Early Dwarf Erfurt

Early Snowball.

CELERY

Improved White Plume.

Golden Self Blanching.

Boston Market.

.25

.10
$4 \mathrm{oz}$.

.50

.50

.50

.50

.35

lb.

1.50

1.50

1.50

1.50

1.00

CELERIAC

Giant Smooth Prague

\section{GHERVIL}

Curled

\section{CRESS}

Extra Curled

\section{CORN}

Early: $\quad$ Extra Early Nordheim ..............

Golden Bantam...................

Medium \& Late Crosby's Early.

Potter's Excelsior.

Pint

Quart 


\section{GUCUMBER}

Arlington White Spine

oz. $\quad 4 \mathrm{oz}$.

Extra Long White Spine

.20

.60

Boston Pickling.

.20

.60

.20

.50

Prolific Pickling.

20

.50

Cumberland.

20

Frame Telegraph

pkt.

.35

\section{EGG PLANT}

New York Spineless. .................. .15

Black Beauty ..................... 15

\section{ENDIVE}

White Curled

KOHL RABI

White Vienna

KALE

Dwarf Scotch

\section{LEEKS}

Musselburgh

\section{LETTUCE}

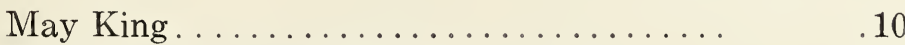

Black Seeded Tennisball. .............. $\quad .10$

Trianon Cos.

\section{MUSHROOM SPAWN}

Pure Culture

per brick

\section{ONIONS}

White Queen..........
Yellow Globe Danvers.

Southport White Globe.

\section{ONION SETS}

White, Yellow, Shallots,

Prices upon Application.

\section{PARSLEY}

Champion Moss Curled.

Champion Triple Curled.

\section{PARSNIPS}

Hollow Crown

\section{PEPPER}

Sweet Mountain 


\section{PEAS}

Long Pod Alaska. Pint
.35

$$
\text { Quart }
$$

60

4 Quart

Peck

Gradus .40

70

2.25

4.00

Thomas Laxton

.40

2.75

5.00

Nott's Excelsior

.40

2.75

5.00

Sutton's Excelsior

Alderman.

Duke of Albany

Early Rose (Selected)

\section{POTATOES}

Green Mountain

Half Moon

Irish Cobbler

Prices upon application.

\section{PUMPKIN}

Mammoth King

oz.

.25

$4 \mathrm{oz}$.

Quaker Pie...

.15

75

Winter Luxury

\section{RADISH}

French Breakfast..................... .20 70

Early Scarlet Globe....................

White Icicle........................ . .

White Box.

SALSIFY

Sandwich Island

\section{SPINAGH}

Long Standing

lb.

Round Thick Leaved....................

Victoria....

New Zealand. .

SQUASH

Summer Crookneck.................... .25

White Scallop ......................

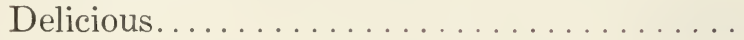

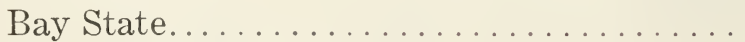

\section{TURNIP}

White Milan .

Snowball..........................

Ruta Baga: American Purple Top ......... 


\section{FERTILIZERS}

The following quotations are for bag and ton lots, but we will be prepared to furnish any smaller quantity to those with small gardens.

BONE MEAL

100-lb. Ton

PHOSPHATE

For general crops $2-8-3 \ldots \ldots \ldots \ldots$

$4.00 \quad 75.00$

Special Potato $4-8-4$ 10-lb.

CHARCOAL.

LIME, Agricultural

LEAF MOULD, Screened

NITRATE OF SODA 10-lb. 25-lb.

SHEEP MANURE

\section{INSECTICIDES}

ABOL. Both an insecticide and fungicide; highly recommended...1 quart

ARSENATE OF LEAD. Dry Corona. For all leaf-eating insects 1-2 lb.

ARSENATE OF LEAD. Paste...................... $1 \mathrm{lb}$.

BLACK LEAF 40. Recommended as a spray for all sucking insects.1-2 lb.

BORDEAUX MIXTURE. Liquid. For mildew, rust, scab, and all fungus diseases. . . . . . . . . . . . . . . . 1 quart

BUG DEATH. A non-poisonous powder for all leaf-eating insects. 1 pound

IMPERIAL SOAP SPRAY. One of the best sprays for Red Spider and all insects affecting Roses .................. 1 pint

KEROSENE EMULSION. A valuable remedy for scale........1 quart

LIME \& SULPHUR. Dry. A most effective remedy for scale 
NICO-FUME. Liquid. A nicotine liquid of best quality, used

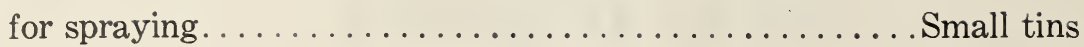

PYROX, Bowkers'. A combination of Arsenate of Lead and Bordeaux Mixture, recommended particularly for potatoes....1 pound

5 pounds

SLUG SHOT, Hammond's. In powder form. Used for all leafeating insects........................... pound

SULPHUR, Corona Dustin. For mildew, etc........... 1 pound

VERMINE. A soil sterilizer; effective against all soil vermin . . . .1-2 pint

WHALE OIL SOAP \& TOBACCO. An excellent wash for plants. . 5 pounds

WEED KILLER. Sterlingworth. For use on walks, etc. $1 \mathrm{lb}$. (makes 15 gals.) 